\title{
The Responses of Pregnant Mares to Visual Stimulation with Special Reference to the Changes in Behavior and Electrocardiogram
}

\author{
Ken-ichi YAYOU ${ }^{1}$, Ryo KUSUNOSE ${ }^{2}$, Kanji MATSUI ${ }^{3}$, Ohki UZAWA ${ }^{1}$, \\ Job Manaet MATIAS ${ }^{1}$, and Shigeru SUGANO ${ }^{1}$
}

${ }^{1}$ Department of Pathophysiology, Faculty of Agriculture, The University of Tokyo, 1-1-1 Yayoi, Bunkyo-ku, Tokyo 113, Japan, ${ }^{2}$ Equine Research Institute, Japan Racing Association, 5-27-7 Tsurumaki, Setagaya-ku, Tokyo 154, Japan, and ${ }^{3}$ Animal Husbandry Experiment Station, Faculty of Agriculture, The University of Tokyo, Iwamamachi, Ibaraki 319-02, Japan

(Received 14 August 1991/Accepted 12 December 1991)

\begin{abstract}
The experiments were performed at Animal Husbandry Experiment Station of the University of Tokyo to investigate the responses of pregnant and non-pregnant thoroughbred mares to visual stimulation with special reference to the changes in behavior and electrocardiogram (ECG), and to evaluate some aspects of the effects of pregnancy on the behavior in mares. Three pregnant and 2 non-pregnant mares were used in this study. Each mare was equipped with a telemeter system for ECG recording, and ECG at their quiet state was recorded for $10 \mathrm{~min}$ in the stall (Quiet Period). Thereafter, each mare was led to the experimental field where a blue vinyl sheet covered life-sized silhouette of a horse drawn with black paint was set up, and her behavior was simultaneously recorded with ECG for 10 min using two time-lapse videorecorders (Prestimulation Period). After a 10-minute Prestimulation Period, the sheet cover was removed and the same recordings were conducted for $10 \mathrm{~min}$ (Stimulation Period). After the visual stimulation, all the mares approached the silhouette and explored it. At the first contact with the silhouette, all pregnant mares explored the head part of the silhouette, while non-pregnant mares began exploration from the parts other than the head. Moreover, the pregnant mares approached the silhouette in a round about way in a variety of gaits with some walking, some trotting and some cantering, while the non-pregnant mares made a beeline for the silhouette at a walking gait. In the unstimulated condition (Quiet Period and Prestimulation Period), the mean heart rates and mean algebraic summations of $\mathrm{T}$-wave amplitude in pregnant mares tended to be higher than those in nonpregnant ones, but, in Quiet Period, significant difference was recognized between both group in mean heart rate levels. Immediately after the visual stimulation, heart rate increased in all mares but, the maximal heart rates in pregnant mares, tended to be higher than those in non-pregnant ones.

Key words: behavior, electrocardiogram, life-sized horse silhouette, pregnant mare, visual stimulation response
\end{abstract}

Jpn. J. Equine Sci. 2 : 41-48, 1991

Some studies have been made on the changes of behavior due to pregnancy in cows or sheep. For instance, Donaldson insisted that the crush order, that is the passing order through a crush from a large holding yard to a smaller one, was different between pregnant and non-pregnant cows [4]. Besides, the other studies on pregnant animals are mainly concerned with ingestive behavior $[1,2,17]$. It is properly thought that the ingestive behavior is different between pregnant and non-pregnant animals, since nutritional demand for fetal growth increases with gestational stage.

On the other hand, it is said that the pregnant mares' behavior in normal life does not greatly alter throughout the period of pregnancy until shortly before parturition [18]. However, subtle behavioral changes could occur that cannot 
Table 1. List of mares used in this experiment

\begin{tabular}{cccc}
\hline Mark of mares & Date of birth & Age (years) & $\begin{array}{c}\text { Stage of gestation } \\
\text { (months) }\end{array}$ \\
\hline A & 1983.4 .12 & 5.67 & 7 \\
B & 1981.2 .14 & 7.83 & 7 \\
C & 1983.3 .24 & 5.75 & 8 \\
D & 1978.2 .11 & 10.83 & \\
E & 1977.4 .6 & 11.67 & \\
\hline
\end{tabular}

A,B,C: Pregnant mare D,E: Non-pregnant mare

be documented without some stimulation since hormonal changes and other physiological alternations exist during pregnancy [5]. It is presumed that the subtle behavioral changes due to pregnancy in normal life could possibly be greater under urgent situations caused by some stimulation.

The behavioral response of pregnant animals to certain kinds of stimulation has not yet been well-known. Concerning the methods for stimulation, Hebb used the objects representing primates, i.e. chimpanzees to formulate an hypothesis for the causes and nature of fear in primates [8]. Williams used horse-like models to investigate the effect of artificial rearing on the social behavior of foals [19]. In order to symbolize another of their own species they used objects, or, models. In the present study, therefore, we tried visual stimulation with a horse-like silhouette to symbolize another of their own species in order to assess the emotionality and the social reactivity of pregnant mares.

The behavior and behavioral response of animals are mainly controlled by the endocrine system and/or nervous system. In particular, the autonomic nervous system has been increasingly evaluated as the modulator of the behavioral response, especially the modulator of the emotional components of behavior [13, 14, 15]. McCann examined the effect of handling of a horse on an emotional level using heart rate response to certain kinds of stimulation $[14,15]$. It was thought, therefore, that emotional responses to visual stimulation in pregnant mares could also be more precisely evaluated by determining heart rate through recording electrocardiogram in the unrestricted condition.

The present study aimed to investigate the difference of response to visual stimulation between pregnant and non-pregnant mares with special reference to changes in behavior and electrocardiogram, and to evaluate some aspects of the effects of pregnancy on behavior in mares.

\section{Materials and Methods}

Experimental procedures. Five thoroughbred mares listed in Table 1 were used in this experiment. They were reared under ordinary conditions in the Animal Husbandry Experiment Station of the University of Tokyo, located in Ibaraki Prefecture, Japan. These mares were given a conventional feed in manger, at 5:30 to 6:00 and $16: 00$ to $16: 30$ twice a day in the stall, and pastured in the paddock from 8:00 to 16:00. The experiment was performed from 9:00 to 15:00 from December 14 th to 15 th, 1988. On the day of the experiment, the mares were tested in their own stalls from 9:00 in random order.

The experimental field was a fenced rectangular enclosure measuring $22 \times 33$ $\mathrm{m}$, as shown in Fig. 1. The field was located apart from the other paddocks. The lifesized horse silhouette was drawn in black on a panel (measuring $1.8 \times 2.7 \mathrm{~m}$ ) placed in the center of the long side of the rectangular. As shown in Fig. 1, numbered plates 


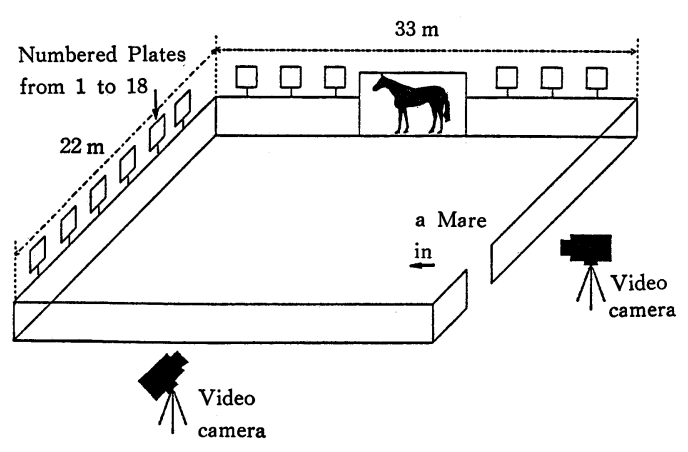

Fig. 1. The schematic view of the experimental field In Prestimulation Period, the silhouette was covered by a blue vinyl sheet, and it was removed at the beginning of Stimulation Period.

(from 1 to 18) were placed 3 meters apart on the two sides indicated to know the position of the subject. Two time-lapse videocameras (Victor, GX N-7) were set up at the center of the other two remaining sides for the behavioral observation.

Experimental procedures were as follows; 1) In the stall where the mares were ordinarily kept, a telemeter system was equipped on each mare and she was left alone for about $5 \mathrm{~min}$ to calm down. Thereafter, electrocardiogram (EGG) was recorded for $10 \mathrm{~min}$ (Quiet Period). Then, 2) Each mare was led to the experimental field where the horse silhouette covered with a blue vinyl sheet was located, and left alone about $5 \mathrm{~min}$ to calm down. Next, the behavior and ECG were recorded for 10 min (Prestimulation Period). Then, 3) The silhouette cover was successively removed and the behavior and ECG were recorded for $10 \mathrm{~min}$ (Stimulation Period).

Recording and analysis of behavior and ECG. Two videocameras were operated to follow movement of the mares. To analyze the position of the mare at any given point of time, the point of intersection of two lines drawn between the video camera and the numbered plate behind each mare, was plotted on $1 / 200$ scaled paper.

In the first approach to the silhouette by each mare, the items analyzed were, as to pattern of approach, in other words, from the presentation of the visual stimulation to the onset of the first silhouette exploration, the required time, the cumulative distance of movement and the distance from the horse silhouette, and, as to olfaction exploration sequences of the parts of the silhouette, i.e., the head, abdomen, nates, hind legs, front legs, neck, inguen, tail, pectus and the back of the silhouette board.

ECG was monitored with FM transmitter (Fukuda Denshi, ST-17), powered by two alkaline batteries. The completed unit has the size of approximately $10 \mathrm{~cm} \times 6 \mathrm{~cm}$ $\times 2 \mathrm{~cm}$. It was inserted into a pocket on a belly band which was fastened to the back of the animal by means of magic tape. The transmitter was connected with a 7 $\mathrm{cm}$ hand-made antenna attached on the top of the belly band.

ECG was recorded in A-B lead. The electrodes (3M Yakuhin) were attached along the longitudinal heart axis; the positive electrode was placed at the position of apex and the negative electrode at the position of base of the heart. The signal from transmitter was sent to the FM receiver (Fukuda Denshi, SR-11). The output of the receiver was successively recorded on an ECG processor (Softron).

The mean heart rates and mean algebraic summations of $\mathrm{T}$-wave amplitude in Quiet Period and Prestimulation Period and maximal heart rates in Stimulation Period were continuously calculated from the R-R intervals in ECG records obtained, and the pregnant and non-pregnant group were compared.

For statistical evaluation, Wilcoxon plus order test and Student's t-test were used.

\section{Results}

Just after the cover of the horse silhouette was removed, all mares were surprised by the sound of removing the cover, but they immediately began to approach the horse silhouette and explored it. 
Table 2. The sequences of the exploring parts at the first approach by each mare to the horse silhouette

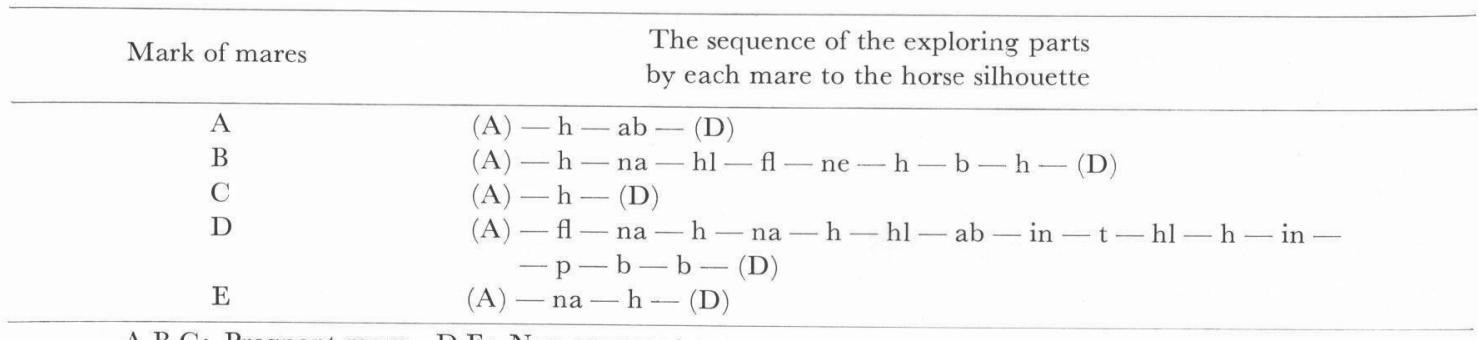

A,P,C: Pregnant mare D,E: Non-pregnant mare

(A): Approach to the silhouette, (D): Depart from the silhouette

Small alphabets represent the exploring parts; $h$ : the head, ab: the abdomen, na: the nates, hl: the hind legs, fl: the front legs, ne: the neck, in: the inguen, $t$ : the tail, $\mathrm{p}$ : the pectus, and $\mathrm{b}$ : the back of the silhouette board.

The pattern of silhouctte exploration in the first approach to the silhouette by each mare differed between pregnant and nonpregnant mares. The sequences of the exploring parts in the first approach by each mare are presented in Table 2. All the pregnant mares explored the head of the silhouette at first, while the non-pregnant mares the other parts, i.e. front legs or nates.

The type of the first approach to the silhouette by each mare also differed between pregnant and non-pregnant mares. Pregnant mares approached the silhouette in a round about way, while non-pregnant mares made a beeline for the silhouette. The required time and the cumulative distance from the presentation of the visual stimulation to the onset of the first silhouette exploration are shown in Table 3 (a) and (b). Pregnant mares tended to take longer time and longer movement than non-pregnant ones from the presentation of the visual stimulation to the onset of the first silhouette exploration $(p<0.1$, Wilcoxon plus order test). Changes in the distance between the silhouette and each mare from the presentation of the visual stimulation to the onset of the first silhouette exploration are shown in Fig. 2. This figure indicates that all the pregnant mares approached the silhouette in a round about way in a variety of gaits with some walk-
Table 3. The required time (sec) (a) and the cumulative distance $(m)$ (b) from the presentation of the visual stimulation to the onset of the first silhouette exploration

(a)

\begin{tabular}{|c|c|c|}
\hline Rank & $\begin{array}{l}\text { Pregnant } \\
\text { mares }\end{array}$ & $\begin{array}{c}\text { Non-pregnant } \\
\text { mares }\end{array}$ \\
\hline 1 & & $21 \quad(\mathrm{D})$ \\
\hline 2 & & $34 \quad(\mathrm{E})$ \\
\hline 3 & $37 \quad(\mathrm{~A})$ & \\
\hline 4 & 63 (C) & \\
\hline 5 & 69.5 (B) & \\
\hline
\end{tabular}

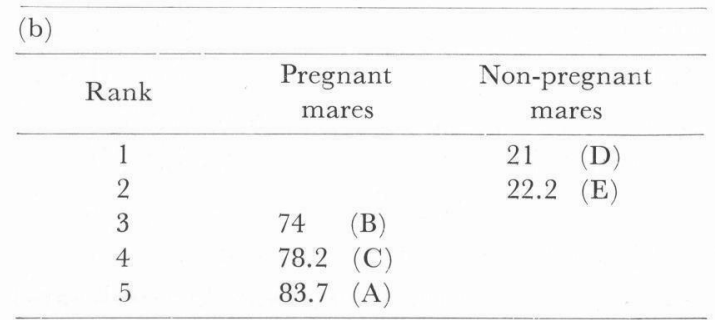

The numbers in this table are arranged for Wilcoxon plus order test.

The alphabets indicate pregnant (A, B, C) and nonpregnant (D, E) mares.

Pregnant mares tend to take longer time and longer movement than non-pregnant ones from the presentation of the visual stimulation to the onset of the first silhouette exploration $(\mathrm{p}<0.1$, Wilcoxon plus order test).

ing, some trotting and some cantering, while two non-pregnant mares made a beeline for the silhouette at a walking gait.

Mean heart rates and mean algebraic summations of T-wave amplitude in Quiet Period and Prestimulation Period are presented in Table 4. In both Quiet Period and Prestimulation Period, mean heart rates 
Table 4. The mean heart rates and mean algebraic summations of T-wave amplitude in Quiet Period and Prestimulation Period

\begin{tabular}{|c|c|c|c|c|}
\hline \multirow[b]{2}{*}{ Mark of mares } & \multicolumn{2}{|c|}{ Quiet Period } & \multicolumn{2}{|c|}{ Prestimulation Period } \\
\hline & $\begin{array}{l}\text { Heart rate } \\
\text { (bpm) }\end{array}$ & $\begin{array}{l}\text { T-wave } \\
\text { amplitude } \\
\quad(\mathrm{mV})\end{array}$ & $\begin{array}{c}\text { Heart rate }{ }^{2)} \\
(\text { bpm })\end{array}$ & $\begin{array}{l}\text { T-wave } \\
\text { amplitude }^{3)} \\
(\mathrm{mV})\end{array}$ \\
\hline A & 48 & 0.54 & 76 & 0.83 \\
\hline $\mathrm{B}$ & 44 & 0.55 & 52 & 0.57 \\
\hline $\mathrm{C}$ & 40 & -0.06 & 65 & 0.21 \\
\hline $\mathrm{D}$ & 35 & -0.36 & 44 & 0.37 \\
\hline $\mathrm{E}$ & 33 & 0.09 & 38 & -0.17 \\
\hline
\end{tabular}

A,B,C: Pregnant mares D,E: Non-pregnant mares

1) Obtained from 10 min sampling during Quiet Period

2) Obtained from 5 min sampling at the second half of Prestimulation Period.

3) Obtained from 2 min sampling in the successive part where the constant wave form was shown.

In both Quiet Period and Prestimulation Period, mean heart rates and mean algebraic summations of T-wave amplitude tended to be higher in pregnant mares than those in non-pregnant ones, and in Quet Period, mean heart rates in pregnant mares were significantly higher than those in non-pregnant ones $(\mathrm{p}<0.05$, Student $t$-test $)$.

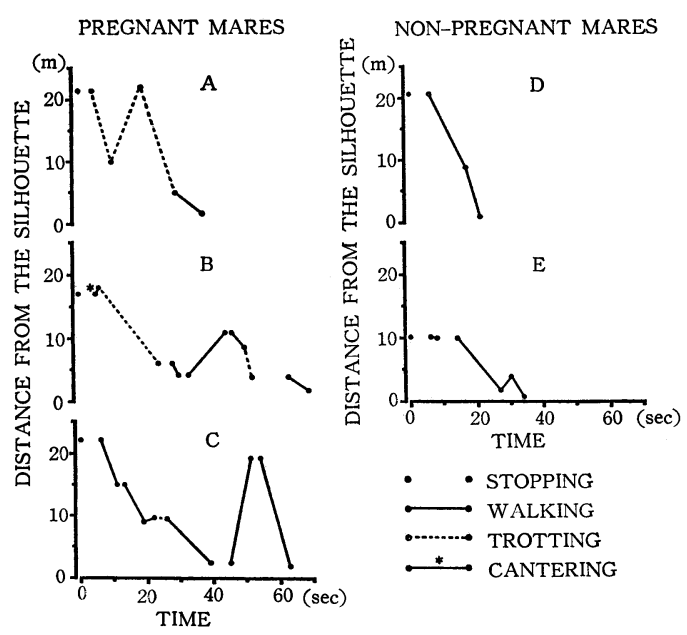

Fig. 2. Changes in the distance between the silhouette and each mare from the presentation of the visual stimulation to the onset of the first silhouette exploration

and mean algebraic summations of $\mathrm{T}$-wave amplitude tended to be higher in pregnant mares than in non-pregnant ones. Especially in Quiet Period, mean heart rates in pregnant mares were significantly higher than those in non-pregnant ones $(p<0.05$, Student $t$-test).

The gains and increasing rates calculated from the maximal heart rates in Stimulation Period and mean heart rates in Prestimulation Period are shown in
Table 5. The gains and increasing rates calculated from the maximal heart rates in Stimulation Period and the mean heart rates in Prestimulation Period

\begin{tabular}{cccc}
\hline $\begin{array}{c}\text { Mark of } \\
\text { mares }\end{array}$ & $\begin{array}{c}\text { Maximal heart } \\
\text { rate (bpm) }\end{array}$ & $\begin{array}{c}\mathrm{a} \\
(\mathrm{bpm})\end{array}$ & $\begin{array}{c}\mathrm{b} \\
(\%)\end{array}$ \\
\hline A & 144.2 & 68.2 & 89.7 \\
B & 159.6 & 107.6 & 206.9 \\
C & 180.7 & 115.7 & 178.0 \\
D & 98.7 & 54.7 & 124.3 \\
E & 129.3 & 91.3 & 240.3
\end{tabular}

A, B, C: Pregnant mares D,E: Non-pregnant mares a: The gains calculated from the maximal heart rates in Stimulation Period and the mean heart rates in Prestimulation Period.

b: The increasing rates calculated from the maximal heart rates in Stimulation Period and the mean heart rates in Prestimulation Period.

Table 5. Although maximal heart rates in pregnant mares tended to be higher than those in non-pregnant ones, there were no significant difference in the gains and increasing rates calculated from the maximal heart rates in Stimulation Period and the mean heart rates in Prestimulation Period between pregnant and non-pregnant mares.

\section{Discussion}

All mares approached the horse silhouette and explored it. They explored the silhouette along its body, and thereafter 
one pregnant mare and one non-pregnant mare investigated the back of the silhouette board. Grzimek reported that the normally raised horses responded to the visual models or the likeness of equine as they would respond to strange members of their own species [6]. It is known, moreover, that the first contact with each other starts from nostrils, when two horses meet for the first time [7], and that the two horse partners usually face each other, standing so that one shoulder is close to the corresponding shoulder of the partner [18]. In this experiment, pregnant mares explored the head part of the silhouette, especially the nostrils at first, judging from the fine observation of video-taped recording, while non-pregnant mares did not face the silhouette and began the exploration of silhouette from the parts other than the head. Unlike non-pregnant mares, pregnant mares responded to the horselike silhouette at first approach as if it were a strange living horse. At least, it can be said that the horse-like silhouette was effective as a visual stimulation method and it might be accepted as a difference between pregnant mares and non-pregnant ones.

It is said that exploratory behavior reveals curiosity and flight fear [9]. Stimulation at low levels elicits exploratory behavior and that at higher level evokes flight corresponding to the threshold which depends on the internal state of the animal, so that an animal encountering a novel object is in a state of conflict as to whether to flee or explore [3]. In the present study, after the visual stimulation, all the mares explored the horse silhouette, but the pregnant mares approached the silhouette in a round about way, while non-pregnant mares made a beeline for the silhouette. This suggests that pregnant mares were in a state of conflict as to whether to flee or explore.

The maternal heart rate in mares in- creases with gestational age $[10,12]$. In the present results, also, the mean heart rates of pregnant mares were significantly higher than those of non-pregnant ones in Quiet Period, and moreover, the mean algebraic summations of $\mathrm{T}$-wave amplitude as an index of sympathetic nervous activity [11] tended to be higher in pregnant mares than in non-pregnant ones. These suggest that cardiac sympathetic activity in pregnant mares was higher than that in nonpregnant ones. It is increasingly known that the autonomic nervous system acts as a behavioral modulator, and generally modulates the intensity of behavioral responses, especially the emotional components of behaviors [13]. The high sympathetic activity of pregnant mares might influence behavioral reactivity to visual stimulation.

It is well-known that the change in heart rate has direct relations with movement or behavior types [16]. This relation has also been observed in the present experiment, but there were some differences between Stimulation Period and Prestimulation Period, as to the change in heart rate related to identical movements. It is probably due to the emotional factors. On the other hand, maximal heart rates in pregnant mares tended to be higher than those in non-pregnant ones. The changes in heart rate, however, might not be a precise index of emotionality, since the kind of movement differed between pregnant mares and non-pregnant ones, i.e. pregnant mares mixed walking and trotting or cantering, while non-pregnant mares only walked.

The physical load increases with advancing gestation. This is a life-and-death problem for the prey animals in the wild life, because they have to escape from predatory animals. In order to cope with this problem, it is presumed that the present results show an example for such adaptation, namely, the sense of sight, 
smell, or hearing in the prey animals may be accelerated and their watchfulness may be raised.

\section{Acknowledgements}

The authors thank the members of the Animal Husbandry Experiment Station, the University of Tokyo for their support on this experiment.

\section{References}

1. Arnold, G. W. (1975). Herbage intake and grazing behaviour in ewes of four breeds at different physiological states. Aust. J. Agric. Res. 26: 1017-1024.

2. Arnold, G. W. and Dudzinski, M. L. (1967). Studies on the diet of the grazing animal. II. The effect of physiological status in ewes and pasture availability on herbage intake. Aust. J. Agric. Res. 18: 349-359.

3. Bischof, N. (1975). A systems approach toward the functional connections of attachment and fear. Child Dev. 46: 801-817.

4. Donaldson, L. E. (1963). A connection between pregnancy and crush order in cows. Anim. Behav. 11: 286.

5. Ginther, O. J. (1979). Reproductive Biology of the Mare; Basic and Applied Aspects, pp. 321-358. Univ. of Wisconsin. Michigan.

6. Grzimek, B. (1943). Self-recognition in horses (trans. title). Z. Tierpsychol. 5: 465.

7. Hafez, E. S. E., Williams, M., and Wierzbowski, S (1969). The behaviour of horses. In: Hafez, E. S. E. (ed.), The Behaviour of Domestic Animals, 2nd ed., pp. 391-416. Bailliere, Tindall \& Cassell, London.

8. Hebb, D. O. (1946). On the nature of fear. Psychol. Rev. 53: 259-276.

9. Hinde, R. A. (1966). Animal Behaviour, pp. 349-
356. McGraw-Hill, New York.

10. Matsui, K. (1985). Fetal and maternal heart rates in a case of twin pregnancy of the throughbred horses. Jpn. J. Vet. Sci. 47: 817-821.

11. Matsui, K. and Sugano, S. (1987). Species differences in the changes in heart rate and $\mathrm{T}$-wave amplitude after autonomic blockade in throughbred horses, ponies, cows, pigs, goats and chickens. Jpn. J. Vet. Sci. 49: 637-644.

12. Matsui, K., Sugano, S., and Masuyama, I. (1985). Changes in the fetal heart rate of thoroughbred horse through the gestation. Jpn. J. Vet. Sci. 47: $597-601$

13. McBrooks, C. C. (1981). The autonomic nervous system, molder and integrator of function. Review of a concept. Brazil. J. Med. Biol. Res. 14: 151-160.

14. McCann, J. S., Heird, J. C., Bell, R. W., and Lutherer, L. O. (1988). Normal and more highly reactive horses. I. Heart rate, respiration rate and behavioral observations. Appl. Anim. Behav. Sci. 19: 201-214.

15. McCann, J. S., Heird, J. C., Bell, R. W., and Lutherer, L. O. (1988). Normal and more highly reactive horses. II. The effect of handling and reserpine on the cardiac response to stimuli. Appl. Anim. Behav. Sci. 19: 215-226.

16. Nomura, K., Tokuriki, M., and Nomura, S. (1980). The change of heart rates in horses under the ordinary management in the livestock farm. Jpn. $J$. Zootech. Sci. 51: 823-929.

17. Tribe, D. E. (1950). Influence of pregnancy and social facilitation on the behaviour of the grazing sheep. Nature 166: 74.

18. Warning, G. H. (1983). Horse Behavior, pp. 100, 133-134. Noyes Publication, New Jersey.

19. Williams, M. (1974). The effect of artificial rearing on the social behaviour of foals. Equine Vet. J. 6: $17-18$.

行動および心電図の変化からみた視覚刺激に対する 妊娠馬の反応一一矢用健一 ${ }^{1}$, 楠瀬 良 $^{2}$, 松井寛二 ${ }^{3}$, 鵜澤巨樹 ${ }^{1}$, ジョブ マナエット マティアス ${ }^{1}$, 菅野 茂 ${ }^{1}$ ( ${ }^{1}$ 東京大学農学 部比較病態生理学教室 干113 東京都文京区弥生1-1-1， ${ }^{2} \mathrm{JRA}$ 競走馬総合研究所 $干 154$ 東京都世田谷区弦巻5-27-7, ${ }^{3}$ 東京大学農学部附属牧場 干319-02 茨城県西茨城郡岩間町 安居)

サラブレッド種妊娠馬と非妊娠馬の，視覚刺激に対する反応性の相違を行動および心電 図を指標として調べ，妊娠が雌馬の行動に及ぼす影響の一端を明らかにすることを目的と した。実験には，妊娠馬 3 頭と非妊娠馬 2 頭を用いた。まず，馬房内で各供試馬に心電図 送信用テレメーターを装着後，安静状態で 10 分間にわたり心電図を記録した（安静期）。 ついで，覆いをかけた視覚刺激用のウマ型等身大シルエットを設置した実験フィールドに 連れ出し，10分間の心電図記録を行った。また，この時から供試馬の行動とフィールドに おける位置を 2 台のビデオレコーダーにより同時に記録した（馴致期）。さらに 馴致期終 了後シルェットの覆いを取り除き，シルェットに対する反応を10分間にわたり同様の方法 で観察した（刺激期）。シルェット提示後，供試馬は全頭シルェットに接近し探索行動を 
行ったが，最初の探索行動において，妊娠馬は全頭シルエットの頭部から探索を開始した のに対して，非妊娠馬では頭部から探索を開始した個体はいなかった。また，非妊娠馬は 短時間で直線的にシルェットに到達して探索行動を行い，その間の歩様も常歩のみであっ たのに対して，妊娠馬は迂回して比較的長い時間をかけてシルェットに到達し，その間の 歩様には速歩あるいは駆歩が混じっていた。一方，安静期に括ける平均心拍数は妊娠馬が 非妊娠馬より有意に多く, 馴致期の心拍数抢よびT波振幅代数和の平均值も妊娠馬の方が 高い傾向にあった。視覚刺激後の心拍数は妊娠馬, 非妊娠馬ともに増加し, その時の最高 心拍数は有意ではなかったが妊娠馬の方が大きい傾向にあった。 